\title{
FOLR1 Gene
}

National Cancer Institute

\section{Source}

National Cancer Institute. FOLR1 Gene. NCI Thesaurus. Code C39283.

This gene is involved in the mediation of 5-methyltetrahydrofolate delivery to the cellular interior. 